\title{
Gender (in)equality contested: externalising employment in the construction industry
}

\author{
Gunilla Olofsdotter and Maria Rasmusson
}

\begin{abstract}
In construction and engineering, workers from different organisations work together, often on a project-by-project basis. Drawing on the theoretical framework of inequality regimes as presented by Acker (2006a), and the externalisation of employment relations presented by Kalleberg et al. (2003), this article investigates the gendered implications of the externalisation of technological work in the construction industry. The empirical material is based upon interviews and a questionnaire answered by regular employees, contracted staff and independent contractors working in the construction industry. The data reveal how non-standard employments are parts of the organising processes that produce gendered inequalities between core and peripheral workers. This finding does not suggest that peripheral work indicates poor working conditions, to be more precise, peripheral workers can be in the most privileged positions.
\end{abstract}

Keywords: project work, construction industry, gender, externalisation, inequality regimes, engineering.

\section{Introduction}

The minority position of women in the science, engineering and technology (SET) professions has been a concern for years in Sweden (Statskontoret, 2009; SCB, 2014) and in other countries (Gale, 1994; Dainty et al., 2004; Adams and Weiss, 2011). Because women are under-represented in technology fields (Adams and Weiss, 2011), organisations have recognised the benefit of retaining the few women who are in the industry (Sappleton and Takruri-Rizk, 2008). The lack of women in SET professions has been explained, for example, as a result of individual choice, discrimination, work-family responsibilities, interests and organisational leadership (e.g. Acker, 1990; Agapiou, 2002; Eriksson-Zetterquist and Knights, 2004; Watts, 2007, 2009a,b; Wajcman, 2008; Styhre, 2011). In a study of the factors that influence the matching of women to science and technology occupations, Srinivas found that it is more difficult for women to succeed. Although educational achievement and educational choice play an important role in occupational choices, she found that 'education plays a much smaller role in occupational matching for women compared with men' (Srinivas, 2011:153). In a study of men and women who aspire to be technology leaders, Adams and Weiss (2011) reported that the stereotypical view that women are better at working with people might work in

Gunilla Olofsdotter (Gunilla.olofsdotter@miun.se) is Associate Professor in Sociology and is affiliated to Department of Social Sciences, Mid Sweden University, Sundsvall, Sweden. Maria Rasmusson (Maria.rasmusson@miun.se) is Senior Lecturer in Education and is affiliated to Department of Education, Mid Sweden University, Härnösand, Sweden 
women's favour in terms of their aspirations, indicating that the explanations for the shortage of women in technological work have been varied and, to some extent, contradictory. The gendered division of labour is also present in the construction industry, in which workers from different organisations work together, often on a project-by-project basis. Construction is technology-intensive work that demands technological specialists and managers and manual labour. In contrast to the images of organisations as sites of stability and continuity, project organisations 'represent temporary groupings where multiple roles, identities, tasks and activities intersect for a time before being dissolved and recombined into new projects'. One feature of project-based work is that it is a culture that is characterised by mobility, self-employment and a fragmented and unstable environment (Paap, 2006; Watts, 2009b; Ness, 2012:117). This feature indicates that the actual work is conducted by workers who are employed by the project owner, subcontractors, contract workers or independent contractors (Purcell and Purcell, 1998; Kalleberg, 2000; Green, 2006) at different hierarchical levels. Nevertheless, in modern organisations, the activities are often organised into multiple projects (Yeow, 2014) consisting of different disciplines, functions and organisations (Marshall, 2003:66). Construction projects are no exception, and they are often established in multiorganisational coalitions to achieve their purposes (Green, 2006:232). Researchers have investigated such changes in organisational structures and processes in terms of, for example insourcing and outsourcing (Purcell and Purcell, 1998), the fragmenting of work across organisational boundaries (Grimshaw et al., 2005; and the externalising of employment relations (Kalleberg et al., 2003) and non-standard employment relations (Kalleberg, 2000). The movement of employees from one organisation to another organisation leads to the blurring of organisational boundaries, indicating that the boundaries of an organisation are 'not spatially, but contractually defined' (Garsten, 2003:247) and that obligations, identifications and allegiances are 'negotiable rather than stable' (Grimshaw et al., 2005:2). These different approaches emphasise the divisions of workers in different locations, organisations and contractual statuses. These changes have often been explained by increased competition in the global labour market and the need for numerical and functional flexibility (e.g., Atkinson 1984; Reilly, 1998; Kalleberg, 2009). These flexibility strategies can be mixed in different manners to achieve flexibility within organisations (Voudouris, 2007). However, flexibility can be mutually beneficial for employers and employees (Reilly, 1998). As a consequence of these strategies, the organisation is divided into a core of employees and a periphery of workers with non-standard employment. Nevertheless, there are no clear-cut divisions between what can be characterised as good or bad jobs (Kalleberg, 2013). However, such flexible work arrangements can lead to new forms of inequalities between workers (Garsten, 2003) and can involve 'overt and suppressed conflicts as well as pragmatic elements of cooperation' (Grimshaw et al., 2005:2). The division of labour also has gendered implications. In terms of occupations, hierarchies and power relations, the mechanisms of gender segregation in the workplace have been changing very slowly. The construction industry is no exception to this tendency. As increasing numbers of operations across industries have become redefined as projectbased, little critical attention has been directed toward the implications of this development for both organisations and employees (Hodgson, 2002:803) or for the lived realities of the construction industry's workforce (Green, 2006:233). Therefore, consistent with Eriksson-Zetterquist and Knights (2004:192), we suggest that it is important to 'provide a gender analysis of job segregation' and an analysis of 'the exclusion of women from the technological arena'. We argue that the externalisation of employment relations in project work can affect, challenge and change existing power relations, organisational practices and gender relations in organisations.

Our aim is to investigate the gendered implications of the externalisation of technological work in the construction industry. Does the externalisation of technological work increase women's opportunities in the construction industry or result in increased segregation between male and female workers? 
The analysis is inspired by the theoretical framework of 'inequality regimes', as presented by Acker (2006b), and the externalising of employment relations presented by, for example, Kalleberg et al. (2003). This study is established from a constructionist gender perspective in which organisational practices, processes and activities are interpreted as constituting an ongoing construction of inequality regimes. The empirical material that is presented in this article is based on individual interviews and a questionnaire that was completed by regular employees, contracted staff from consultant agencies and independent contractors. The article contributes to the field of Critical Project Studies with new insights into how particular patterns of inequality are (re)produced by emphasising a description of inequalities, based on a quantitative analysis, and the experiences of externalising employment, based on a qualitative analysis.

The paper is structured as follows. In the first part, we provide a short overview of the theoretical perspectives. In the second part, the study's research design is described. The third part presents the results, followed by a concluding discussion in the fourth part.

\section{Inequality regimes and externalisation of employment relations}

Feminist researchers have continually studied the gendering of organisations and organisational practices to understand how gendered inequalities persist in organisations despite numerous attempts to eliminate them (e.g. Acker, 1990, 2012; Abrahamsson and Gonäs, 2014). Certain rules, codes and norms that prescribe workplace behaviour are inherent in all organisations. These rules and codes are based on the 'abstraction of the disembodied worker', which is an ideological image of the proper worker or manager (Benshop and Doorewaard, 2012:227). Benshop and Doorewaard (2012), as well as Acker (2012), describe the characteristics of the abstract worker as highly qualified, available to work on a full-time basis, and work-oriented as well as commonly presented in organisational texts as (gender) neutral. However, these characteristics are more likely to correspond to the way male workers are conceptualised than female workers (Sappleton and Takruri-Rizk, 2008).

There is a cultural tendency to treat technological work (Eriksson-Zetterquist and Knights, 2004) and project-based work (Lindgren and Packendorff, 2006) as almost exclusively masculine domains, in which masculine norms, such as rationality, authority, competitiveness, and efficiency, are identified as the typical ideals for success, affecting recruitment and promotion (Acker, 1990; Wajcman, 1998; Lindgren and Packendorff, 2006; Sappleton and Takruri-Rizk, 2008). Although construction projects are embedded within organisational contexts, Lindgren and Packendorff (2006:863) demonstrate that the temporality of projects makes it possible to apply different norms than those outside of the project, in turn, making the 'tendency to reproduce traditional masculinities even stronger'. Similarly, Crevani and Shinozaki Lennerfors (2009:117) found that project work in the construction industry reproduces inequalities in practice and that a 'reconstruction of competence is intertwined with the construction of (certain) masculinities', indicating that an increase in the number of women working in businesses might not be sufficient to change this masculine culture (Gale and Cartwright, 1995). As a consequence, women as minority workers are outside of the power networks and have limited opportunities to develop their careers (Watts, 2007:303). Gender inequality becomes even more visible in management positions, and 'the glass ceiling' metaphor emphasises the barriers that prevent women from ascending the career ladder (Oakley, 2000).

To identify the barriers to equality in organisations, Acker developed the concept of inequality regimes as a means of examining the production and reproduction of complex inequalities in organisations (Healy et al., 2011; Mulinari and Selberg, 2013). According to Acker, the idea of inequality regimes can be used to identify inequality-producing practices and their locations in particular organising processes' (Acker, 2009:201). In contrast to ideas regarding 'gender regimes', 
analyses based on inequality regimes recognise that gender are involved in processes that are related to class and/or race (Acker, 2009). The externalisation of employment relations that is 'designed to increase organisational flexibility' by moving some parts of the employment relationship outside of the organisation is one example of how organising processes could influence inequality-producing practices. This movement can be accomplished in different manners, including the use of temporary work agencies for contract workers and limiting the duration of employment through part-time work or short-time hires. Externalisation raises important issues for research on organisations and social stratification and highlights problems linked to workplace inequality' (Kalleberg et al., 2003:526). Some non-standard work arrangements, such as some part-time work and temporary work, are associated with insecure jobs, while other forms such as 'subcontracting provide opportunities for entrepreneurs and independent contractors to obtain flexible employment' (Kalleberg et al., 2003:526). In the present paper, we focus at the gendered implications of the externalisation of technological work. Acker (2006b) suggests that research on inequality should pay attention to the local practical activity of organising work and its intersections. Inequality regimes exist in all organisations and can be defined as loosely interrelated practices, processes, actions, and meanings that result in and maintain class, gender and racial inequalities within particular organisations' (Acker, 2006b:443). Acker defines inequality in organisations as follows:

systematic disparities between participants in power and control over goals, resources, and outcomes; in workplace decision-making such as how to organise work; in opportunities for promotions and interesting work; in security in employment and benefits; in pay and other monetary rewards; and in respect and pleasures in work and work relations (Acker, 2009b:202)

The externalisation of employment relations has resulted in increased segmentation between workers in the core and those in the periphery. However, peripheral workers are heterogeneous and include both highly skilled, 'well-paid workers as well as low-skilled, low-paid workers' (Kalleberg, 2003:156). Such segmentation is part of the practices and processes that create inequalities in organisations (see Acker, 2006a,b). Moreover, it is important not to view core and peripheral workers as working in separate parts of organisations because they might have the same job within the same department (Kalleberg, 2001). That is, peripheral work does not necessarily indicate poor working conditions. Rather, Kalleberg (2003:156) suggests that the consequences of working in non-standard employment relations differ in terms of workers' 'degree of market power, or the extent to which they are able to control the terms of their employment'. This highlights that the employment relations is not the only explanation behind inequalities in organisations. For example, employees in the periphery, such as independent contractors and consultants, may have highly portable skills and other workers, such as short-time hires in routine jobs, may have non-transferable skills (Kalleberg, 2009:164).

The sources of workers' market power or degree of control over their employment situations are rooted in their possession of skills that are in high demand and are highly valued and marketable (human capital), as well as their network connections and memberships in various kinds of social groups (social capital), which allow them to learn about and acquire good jobs (Kalleberg, 2013:78).

The above quotation shows an example of how organising practices are 'essential elements of class practices' (Acker, 2006a:107). Thus, the concept of inequality regime highlights organisational processes that produce gendered class relations (Acker, 2006a). Acker (2006b, 2009) distinguishes between the following six varying characteristics of inequality regimes. (1) The bases of inequality vary between organisations, but gender, class and race processes are typically present. (2) The shape and degree of inequality, such as the steepness of the hierarchy and the segregation of jobs and occupations, are typically gendered and racialised (Acker, 
2006b:446). (3) Organising processes that produce inequalities include for example: opportunities for flexibility; jobs and wage classifications systems, recruitment, hiring and promotion, wage setting and supervisory practices; (Acker, 2006b:451). (4) The visibility of inequalities is the degree of awareness of inequalities in organisations (Acker, 2009:211). (5) With the legitimacy of inequalities, some inequalities are accepted as normal, for example between managers at different levels and between mangers and non-managers. (6) Control and compliance refers primarily to maintaining the power of managers and ensuring that workers act in accordance with organisations' goals through controls, including unobtrusive or indirect controls and internalised controls.

As previously mentioned, in the construction industry, work is typically conducted by workers who are employed by the project owner, contract workers or independent contractors (e.g. Green, 2006). Contracting is used to provide skills that are not available in the organisation, reduce costs and meet increased demands. In contract work, the contract company typically supervises its employees, but the degree of control exercised by clients is not clearly defined. These employees can work on the clients' premises or off site. Independent contractors, by contrast, are self-employed. They have no wage contract and no employer and are responsible for their own taxes, which indicate that they accept the economic risks and control their own work (Purcell and Purcell, 1998; Kalleberg, 2000). Nevertheless, Barley and Kunda (2004) demonstrate that the growth of independent contracting has created opportunities for skilled workers, indicating that independent contractors in project management can be described as a type of expert involved in a process of professionalisation (Paton et al., 2013). Thus, our theoretical framework will combine Kalleberg's concept of externalisation of employment relations and Acker's concept of inequality regimes. Consistent with Healy et al. (2011:483), we argue that the concepts of inequality regimes are useful tools for revealing the complexity of inequalities in organisations. These concepts can be analytically isolated, but in practice, they are mutually constituted and in constant processes of construction'. In her later writing, Acker (2012) underlines the persistence of inequality regimes in organisations and argues for further research on the complexity and variety of inequality regimes in the context of contemporary changes. For example, have 'organisational logics changed with new forms of employment and new types of dispersed organisations?' and 'how do these logics deal or not deal with gender, race and class inequities?' (Acker, 2012:222). According to these suggestions, it is relevant for us to integrate the findings of, for example, Kalleberg (2000, 2003, 2013) on non-standard work arrangements as for example independent contractors and consultants into the concept of inequality regimes.

\section{Methodology}

The gendered implications of the externalisation of employment relations was studied in the empirical setting of the agency responsible for building, maintaining and operating all national roads and railways in Sweden. The organisation was chosen as an example of how operations are organised for project-based work when there is a mix of workers and managers who belong to different organisations participate. Consistent with Dubois and Gadde (2002:554), we argue that 'learning from a particular case (conditioned by the environmental context) should be considered as a strength rather than a weakness'. However, as in all case studies, the findings are particular to the specific organisation at that time. Therefore, Dubois and Gadde (2002) suggest an approach based on 'systematic combining', in which empirical fieldwork, the theoretical framework and case analysis are simultaneously involved. Qualitative data from interviews and quantitative data from a questionnaire were collected in the study. Hence, a mixed-methods approach was adopted to take full advantage of the material. Greene (2007) notes 
that the range of a study can be broadened and more dimensions of a phenomenon can be explored using a mixed-methods approach. In our study, quantitative analysis has allowed us to describe the patterns of inequality by separating between employees, consultants and independent contractors, while qualitative analysis has shown these workers' experiences of how the externalisation of employment relations has created inequalities. Thus, the quantitative data in combination with the qualitative data offers a broader understanding of the gendered implications of the externalisation of technological work in the construction industry.

\section{The quantitative data}

The questionnaire was administered to regular employees, contracted staff from temporary work agencies and consultant agencies and independent contractors, all of whom worked at the organisation. In March 2011, the co-workers received an online questionnaire invitation by e-mail and then received two reminders. In total, 2,135 people received the questionnaire, and the response rate was 50.2 per cent. Non-responses occurred partly because a number of people were no longer employed or contracted, and some of the co-workers declined to answer the questionnaire. The online questionnaire was developed by the researchers on the project, and it covered background information (e.g., age, education and gender) and a number of areas regarding, for example, working conditions, opportunities for career development and the perceived culture at the workplace.

The complete sample was first categorised into eight groups based on the professions that the co-workers listed on the questionnaires. Next, three of these groups were chosen for the subsample that was analysed in this study (see Table 1).

Thereafter, the subsample was divided into three groups according to type of employment: regular employees in the organisation, contracted staff (hereafter referred to as consultants) and independent contractors. Each of these three groups was also divided into male and female groups (see Table 2).

Table 1: Distribution of subsample by occupation and gender

\begin{tabular}{llccc}
\hline & $n$ & $\%$ & $n$ women & $n$ men \\
\hline Engineers & 359 & 56.9 & 70 & 287 \\
Technicians/construction leaders & 118 & 18.7 & 15 & 103 \\
Project managers & 154 & 24.4 & 42 & 112 \\
Total & 631 & 100 & 127 & 502 \\
\hline
\end{tabular}

Table 2: Distribution according to gender and type of worker

\begin{tabular}{lrc}
\hline & $n$ & $\%$ \\
\hline Women & 86 & 13.6 \\
Employees (WE) & 40 & 6.3 \\
Consultants (WC) & 1 & 0.2 \\
Independent contractors (WIC) & & \\
Men & 210 & 33.3 \\
Employees (ME) & 174 & 27.6 \\
Consultants (MC) & 118 & 18.7 \\
Independent contractors (MIC) & 629 & 99.7 \\
Total &
\end{tabular}


After dividing the subsample into groups, these groups were compared using several variables that were derived from the questionnaire data. A selection of the variables were converted into indices; see Table 3 . The reliability of the indices was estimated using Cronbach's alpha and was found to range from 0.6 to 0.9. According to common practice, an estimated reliability greater than 0.5 is sufficient for most purposes (Pedhazur and Schmelkin, 1991). In addition to the indices, individual items from the questionnaire were used in the comparisons of the groups. In the next step, comparisons of the groups were performed by one-way analysis of variance (ANOVA) using SPSS software, version 20.0 (IBM, 2013). IBM SPSS Statistics for Macintosh, Version 20.0. Armonk, NY: IBM Corp. ANOVA assumes equal variances; thus, the variances were tested. In some cases in which this requirement was not met, Welch and Brown-Forsythe tests were used to

Table 3: Overview of the items used from the questionnaire and qualitative interviews distributed according to the analytical model based on inequality regimes (Acker, 2006b, 2009)

\begin{tabular}{|c|c|c|}
\hline Inequality regimes & Variables or interviews & Coding \\
\hline The bases of inequality & $\begin{array}{l}\text { Gender } \\
\text { Age }^{\mathrm{a}}\end{array}$ & $\begin{array}{l}\text { Man }=0, \text { woman }=1 \\
\text { year born }\end{array}$ \\
\hline $\begin{array}{l}\text { Shape and degree of } \\
\text { inequality }\end{array}$ & $\begin{array}{l}\text { Educational level }^{\mathrm{a}} \\
\text { Income }^{\mathrm{a}} \\
\text { Description of occupation }^{\mathrm{a}} \\
\text { Manager }^{\mathrm{a}} \\
\text { Employment (employed, } \\
\text { consultant, free agent) }^{\mathrm{a}} \\
\text { Income }^{\mathrm{a}}\end{array}$ & $\begin{array}{l}5 \text { categories } \\
4 \text { categories } \\
\text { Open categories } \\
\text { Yes }=1, \text { no }=2 \\
1,2 \text { or } 3 \\
4 \text { categories }\end{array}$ \\
\hline \multicolumn{3}{|l|}{$\begin{array}{l}\text { Organising processes that } \\
\text { produce inequality: }\end{array}$} \\
\hline - recruitment and hiring & Qualitative interviews & - \\
\hline - wage-setting practices & Qualitative interviews & - \\
\hline \multirow[t]{6}{*}{$\begin{array}{l}\text { - supervisory relations } \\
\text { informal interactions }\end{array}$} & $\begin{array}{l}\text { My boss encourages and } \\
\text { supports me }\end{array}$ & Agree-higher value \\
\hline & $\begin{array}{l}\text { My boss has clear and } \\
\text { specific aims }\end{array}$ & Agree-higher value \\
\hline & $\begin{array}{l}\text { My ideas are valued } \\
\text { highly (indices) }^{\mathrm{a}}\end{array}$ & Agree-higher value \\
\hline & $\begin{array}{l}\text { I believe others think } \\
\text { highly of my work }^{\mathrm{a}}\end{array}$ & Agree-higher value \\
\hline & $\begin{array}{l}\text { I have the opportunity to } \\
\text { share my knowledge with } \\
\text { others if I want to }\end{array}$ & Agree-higher value \\
\hline & $\begin{array}{l}\text { My professional knowl- } \\
\text { edge is appreciated }^{\text {a }}\end{array}$ & Agree-higher value \\
\hline $\begin{array}{l}\text { Organising the general } \\
\text { requirements of work }\end{array}$ & Qualitative interviews & - \\
\hline $\begin{array}{l}\text { The visibility of } \\
\text { inequalities }\end{array}$ & Qualitative interviews & - \\
\hline $\begin{array}{l}\text { The legitimacy of } \\
\text { inequalities }\end{array}$ & Qualitative interviews & - \\
\hline Control and compliance & Qualitative interviews & - \\
\hline
\end{tabular}

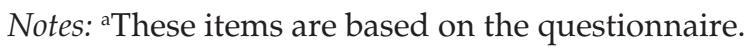


compare the group means. Tukey's HSD was used to identify the groups that displayed differences. In addition, some of the comparisons between the men and the women in the sample were performed using t-tests.

\section{The qualitative data}

Our aim was to explore and analyse the employed and contracted workforces' experiences of the externalisation and the construction of inequality regimes. At the time of the study, all of the interviewees were working full time in the organisation performing technological work. The 22 interviewees were selected by staff within the organisation based on our call for heterogeneity in terms of employment and experience with project work (see Table 4).

The interviews, which lasted between one and one- and a half-hours, were tape-recorded and transcribed verbatim. The interviews were semi-structured and followed a core set of themes: educational background; reasons for choosing the profession; career progression; possibilities for flexibility; collaboration with colleagues regarding recruitment strategy, management, tasks and responsibilities; and the use of agency workers or contract workers. The semi-structured approach allowed for follow-up questions and the interviewees' own reflections.

At the qualitative analysis level, it is important to become familiar with the data and to examine the collected data systematically to identify themes and concepts and to identify patterns that might contribute to an understanding of the studied phenomenon (Fielding and Thomas, 2001:137). Our analysis comprised several steps; after transcription and the first reading of the transcripts, a more careful reading of the interviews followed. The first step was to code the interviews. In connection with a careful reading of the transcripts, concepts or expressions were written in the margins to describe the content. All of the data were coded to reveal recurrent themes, patterns and tensions as well as the positions of each interviewee (Strauss and Corbin, 1998). The transcripts were coded paragraph by paragraph. This procedure is called 'firstlevel coding' (Miles and Huberman, 1994:69) or 'open coding' (Strauss and Corbin, 1998:143). The intention is to reduce the data to analytical categories (Fielding, 2001). The codes can be both analytic, for example, 'identity', and descriptive, for example, wages, education or occupation. The next step was to categorise codes about the same phenomena into themes, thereby reducing the data to smaller units. Miles and Huberman (1994:69) describe this procedure as 'pattern coding'. Then, the encoded material was sorted and added to matrices based on the theoretical concepts of inequality regimes and externalising. We also re-read the theoretical contributions that informed our analysis to clearly observe how theories facilitated our interpretations. This indicates that we combined an open attitude toward the empirical material with our theoretical understanding. We selected interview excerpts as quotes based on

Table 4: Description of interviewees

\begin{tabular}{lllc}
\hline Organisation & Occupation & Gender & Number \\
\hline Employees & Project manager & Men & 5 \\
Employees & Project manager & Women & 3 \\
Independent contractors & Project manager & Men & 5 \\
Consultants (consulting agency) & Project manager & Men & 3 \\
Consultants (consulting agency) & Construction & Men & 6 \\
& manager & & 22 \\
Total & & & 2 \\
\hline
\end{tabular}


the pattern of views that emerged in the matrix. The results are presented as selected quotes from the interviews.

The quantitative data from the questionnaire and the qualitative interviews were analysed in the light of the concepts of inequality regimes, as discussed by Acker, and externalising employment, as described by Kalleberg.

\section{Findings}

The background questions on the questionnaire revealed structural gender differences. The most obvious difference was found in the category of the independent contractors. Because only one woman ( 0.2 per cent of the total workforce) was working as an independent contractor, this employment status seemed almost inaccessible to women; overall, this category included 18.9 per cent of the total workforce. The majority of the women, more than 50 per cent, were regular employees.

As shown in Figure 1, the employed women (WE) and the female consultants (WC) had the youngest mean age among the groups. The group of male independent contractors (MIC) had the oldest mean age among all of the groups. The opposite pattern was found concerning education level (see Figure 2), which, as indicated in the questionnaire, ranged from code 1, for those who attended school until they reached the compulsory age of 16 years old in Sweden, to code 5, for those gained a university degree. The female employees (WE) had a significantly higher level of education than all of the male groups. Female consultants (WC) and male employees (ME) had higher education levels than male consultants (MC) and MIC.

Gender differences were also found in income. Salaries were divided into four categories: code 1 was up to $€ 2,100$ per month, and code 4 was greater than $€ 4,500$ per month. The comparisons (see Figure 3) showed that both the WE and the WC had significantly lower salaries than the three groups of men (ME, MC and MIC). Overall, there were 326 men but only 64 women who earned more than $€ 4,500$, per month, corresponding to 46 per cent of the men and 19 per cent of the women belonging to the highest-paid group in the organisation. The wages among the workers differed between the men and the women. The majority

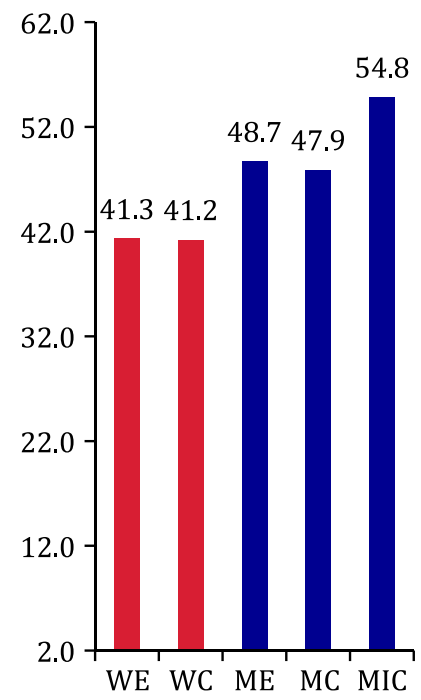

Figure 1: Mean age distributed across the five groups 


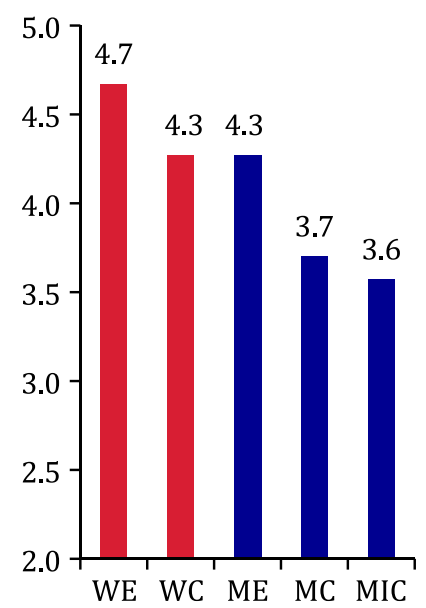

Figure 2: Educational level distributed across the five groups

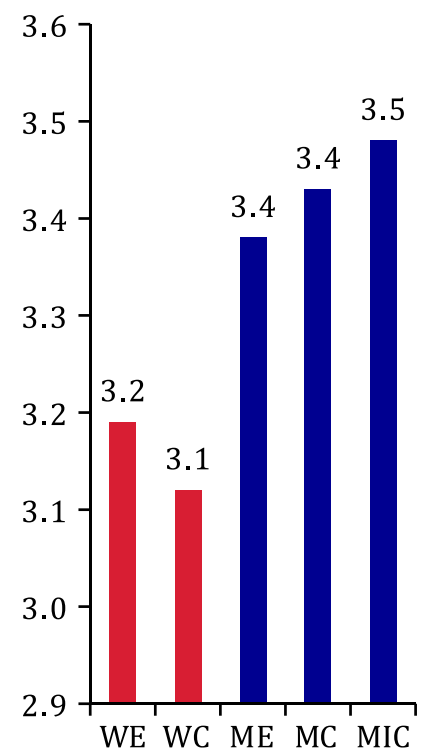

Figure 3: Salary among the five groups

of the men in this occupation received the highest salary, but most of the female workers received the second highest salary.

In sum, it can be stated that the WE had the highest education level but the second lowest salary of workers in all of the groups. Because the independent contractors had the highest mean age, they might also have had the most experience. Presumably, this experience was perceived as desirable by the company because the formal education level of the male independent contractors was the lowest, and their salary was the highest. The salaries of those holding top positions in an organisation are often determined through individual negotiations and thus might be influenced more by the use of subjective values than formalised criteria (Acker, 2009). Thus, the externalisation of employment relations has created intersecting patterns of inequalities. Although independent contractors can be described as peripheral in terms of employment, 
they are in a powerful position as experts with highly portable skills that are in high demand (Kalleberg, 2013). This power makes visible some of the bases of inequalities based on gender, age and class in terms of employment conditions. Two questions arise from the fact that there was only one woman among 119 independent contractors: how this valuable experience is acquired and whether women have the same opportunity to access this experience as men.

The degree and pattern of segregation in terms of jobs and occupations also vary between organisations. Although men and women are found in the same occupations, they are likely to work in different jobs (Acker, 2006b). The segregation between those having different jobs in the organisation was pronounced among supervisors and managers, according to our sample's answers in to a survey question about having a position as a manager or supervisor. Only 13 per cent of the members of the group holding managerial positions were women, and thus, 87 per cent were men. Despite gender equality policies and an increased number of women working in technological fields, there is obviously gender segregation in this type of hierarchical position at this organisation.

The group of men who worked as independent contractors seemed privileged in many ways. One example of this privilege is that they perceived that their ideas and suggestions at work were valuable and were put into practice (see Figure 4).

In addition, the following differences, although not statistically significant, are mentioned here because they are indications of the special features characterising the group of MIC. Their privileged position was also made clear relative to management in the organisation. Such relations could be affected by the genders of both subordinates and management, and in some cases, it resulted in 'preserving or reproducing' gendered inequalities (Acker, 2009:209). The men of this group were among those who most strongly expressed how they received support and encouragement from their manager. Moreover, the MIC also agreed strongly with the following statements: possibilities to share knowledge exist; others think highly of my work; and my professional knowledge is appreciated in the workplace. Members of this group also stated that their bosses had clear and specific aims, indicating that informal interactions influence everyday work and reproduce gendered and class-based inequalities in the organisation.

To conclude, by the externalisation of technological work, consultants and independent contractors have entered the organisation. The quantitative analysis unfolds how these practices have created gendered and class-based inequalities based on

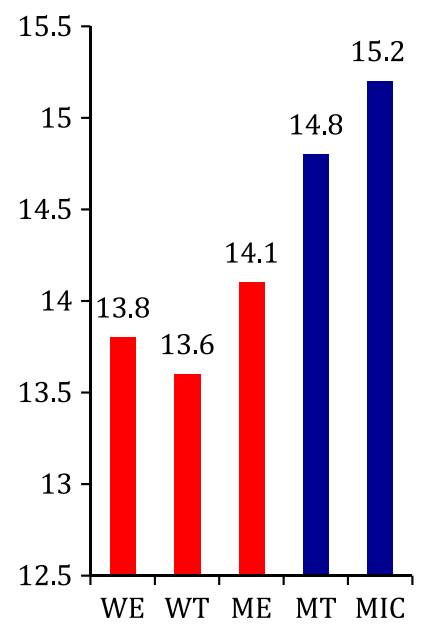

Figure 4: The groups' estimation of the value of their ideas at work (index) 
employment conditions and gender. In the following qualitative analysis, we will exemplify how these practices are experienced and expressed by the workers.

\section{Externalisation as an (in)equality regime}

Although a large part of its operations are carried out in projects, the studied organisation can be described as a traditional bureaucracy with a pronounced hierarchy (see Acker, 2006b). The long-term externalising of technological work has, over the years, become a legitimate strategy in terms of having the 'right' technological expertise. However, this strategy was described as problematic:

The main reason is that [the organisation] made a decision not to employ some categories of workers. We should not handle planning and not employ construction managers, so we sent them away. And now we have to deal with the consequences (WE).

An outcome of this strategy is that the number of employees with technological expertise has decreased. As a consequence, the staff has been divided into a core of employees and a periphery of contracted workers. It was described as a risk when some occupations or jobs were occupied mostly by contracted staff, for example construction managers or economists:

Our economists help us keep up to date with the millions we handle, and they are consultants ... the management has decided that, but I don't think it is good because it feels like consultants are more temporary (WE).

As the quotations show, the organisation selected a strategy of using contracted staff in various positions, including positions with power and influence. This choice indicates that power differences between groups exist not only between those who are employed or contracted. Rather, as Kalleberg (2013) underlines, the degree of power and control over employment situations lies in the possession of valued and marketable skills, which does not necessarily apply to the employees in the core, thus indicating that intersecting patterns of employment conditions and hierarchical positions make the divisions into core and periphery unclear. However, the quantitative analysis has unfolded that these organisational practices also create gendered-based inequalities in, for example, wages (See Figure 3). Nevertheless, the interviewees described the organisation as an organisation that has become more gender equal, and the number of women in technological positions as engineers and project managers has increased.

If you look at [the organisation] generally, I think that there have been some changes toward gender equality. But out on the construction sites or the nearer to the sites you get, the differences increase again (MIC).

Despite these efforts, a gender division in recruitment and hiring was apparent in the interviews. Only a few women engineers and project managers were working in field offices on construction sites. Women were more often found in certain areas, which are at headquarters working in 'softer' areas, such as landscaping and planning. This highlights how organising processes such as recruitment and hiring produce gendered-based inequalities (see Acker, 2006a,b). These different recruitment and hiring strategies were described as based on demands for specific competencies in certain positions:

Most of the jobs at [the organisation] demand university degrees, but on construction sites, practical experience is a valued competence. Today, only a few women choose to work with asphalt or to drive excavators (WE).

The norms and codes about workplace behaviour expressed above are based on an ideological image of a gender-neutral abstract worker (see Acker, 2012) 
where rationality, competitiveness and efficiency are identified as the typical ideals for success (Lindgren and Packendorff, 2006; Sappleton and Takruri-Rizk, 2008). In this case, having the right education is not enough for women to succeed in construction management (see Srinivas, 2011). The importance of having practical experience from work on construction sites and the ability to work one's way up in the hierarchy was also emphasised by an independent contractor:

I'm not saying that they [project managers] have to be 58 years old with 30 years of experience as contractors. However, they must have enough experience not to be deceived. They must be able to be hard on subcontractors and to say, No, you will not get any money; stop nagging, and go away' (MIC).

Thus, the possibility of women being recruited to work for the project owner as project managers or construction managers on construction sites is reduced because the recruitment is based on practical experience from the supply side of business. This means that the externalisation of employment relations has so far not increased the chances for women to make a career in this line of business. Because only a few women work for contractors, their career opportunities are limited.

More and more women are working as subcontractors, so I think it will change. However, it depends on the managers who employ them and the climate they create out in the field. But it is still very tough for girls (MIC).

Although women are beginning to take locations on construction sites, the masculine culture remains a problem to overcome. As shown in the quantitative analysis, only one woman was working as an independent contractor, emphasising that externalisation did not enhance women's opportunities to participate in lucrative positions as independent contractors. Rather, a gendered division between core workers and independent contractors has emerged. Thus, the externalisation of technological work produces hierarchical as well as gendered-based inequalities. The quantitative data revealed gendered differences in education levels, wages and ages among the groups. The independent contractors were found to be the group with the highest salary and the lowest education level (see Figures 2 and 3). These differences were also discussed in the interviews. The higher wages among independent contractors were explained as necessary to recruit workers with technological expertise that is not found among employees in the organisation. These wage differences also make it difficult to tempt independent contractors into becoming employed at STA:

I am not employable there. My guys who work here who are self-employed - they are not employable. They ask for a salary of 80-90,000 SEK, and they are offered 30! Yeah, why the hell should they go there? There is no reason (MIC).

The quotation points out how externalisation creates a systematic wage difference between employees and independent contractors. Despite the awareness of such inequalities, this is to some extent described as a legitimate strategy in order to attract people with the right competence. However, their highly valued competence and experience also places contractors in great demand, which creates problems for the continuity of projects:

The problem is that they jump between companies. So it is unstable. ... Everyone jumps away as soon as someone rattles with their wallets (WE).

Thus, the externalisation has created a situation in which independent contractors have power and control over their situations because their skills are valued and needed, which also places them in a powerful position relative to the organisation (see Kalleberg et al., 2003). As a consequence, inequality exists between workers with the same occupation, with those in the core of operations having lower salaries than the peripheral independent contractors. 


\section{Discussion and conclusion}

In this final section, we return to the article's aim of discussing the gendered implications of the externalisation of technological work. The results unfold how the externalisation of employment created segregating patterns between core and peripheral workers. Nevertheless, this finding does not suggest that peripheral work indicates poor working conditions. Rather, our results showed how peripheral workers can be in the most privileged positions, with a high degree of control over their employment relations (see Kalleberg, 2013). The externalisation of technological work has influenced the shape and degree of inequalities in this organisation such as the steepness of hierarchy (See Acker, $2006 \mathrm{~b})$. The group that stands out in comparison to the others is the independent contractors. They had the highest salaries, the least education and the highest mean age. This group can be compared with female employees, who, among all of the groups, had the highest level of education while having the second lowest salary and a lower mean age. The privileged position of the independent contractors can likely be explained by their lengthy practical experience, and this experience is perceived as desirable by the investigated project-based organisation. The possibilities for women to be recruited as independent contractors were described as limited because the recruitment base consists of former subcontractors with substantial practical experience. The interviews also showed that only a few female engineers and project managers were working in field offices on construction sites. Rather, women worked at headquarters or in areas such as planning and landscaping. Thus, such practices and actions unfold how organising processes such as recruitment, hiring and wage setting are part of the (re)producing of inequalities.

An additional difference among the groups was the higher wages paid to independent contractors, which was explained as a necessity to recruit workers with technological expertise that was not found among the organisation's own employees. The wages also made it difficult to attract independent contractors for employment, emphasising inequality based on wage differences between employees and independent contractors, which also placed the independent contractors in a powerful position relative to the organisation. This highlights how the externalisation of technological work has made such inequalities visible and more or less accepted as a normal, legitimate, part of the organisation (See Acker, 2006b). In Kalleberg's (2013:78) words, contractors are 'in high demand and are highly valued and marketable'. Nevertheless, this organisation was described as having become more gender equal because of the increased number of women in project management and technological positions. However, despite gender-friendly policies and regulations, inequalities based on gender persist in organisations and intersect with class-based inequalities. These inequalities become most obvious when examining recruitment and hiring as women and men continue to be hired for different jobs, despite having the same educational background. Thus, men have a double career path, by earning university degrees and by gaining practical experience from construction sites, giving them an advantageous position in negotiating the terms of their employment or their assignments as independent contractors. However, some women perform work on construction sites and for subcontractors, but this work makes them highly visible, and they are sometimes treated differently than male colleagues. This indicates that organising processes such as recruitment and informal interactions influence everyday work, reproducing gendered and class-based inequalities in this project-based organisation.

The results showed how the externalisation of certain categories of engineers and technicians created a situation in which in-house technical expertise decreased, and the organisation became dependent on consultants and independent contractors. As a consequence, a lucrative and powerful profession was created that fit the ideal image of the highly qualified 'male' abstract worker (See 
Acker, 2012) with practical experience as subcontractors. This consequence indicates that externalisation has, to some extent, segregated women from the lucrative work as independent contractors and has created gender- and classbased inequalities. Acker (2006b) defines inequality in organisations as, for example, differences in 'power and control over goals, resources and outcomes'. Moreover, she argues for the importance of investigating whether 'organisational logics have changed with new forms of employments and new types of dispersed organisations' (Acker, 2012:222). Our results emphasise how non-standard employments and externalisation are parts of the organising processes that produce inequalities. This paper has analysed the data using Acker's theoretical concepts of inequality regimes and Kalleberg's concept of the externalisation of employment relations. These results should prompt further investigations of the intersecting patterns of inequalities by comparing different parts of organisations and organisations in different sectors.

\section{Acknowledgements}

We are grateful to the Swedish Innovation Agency, Vinnova, for funding the project 'Recruitment and innovation processes-A study of the significance of Temporary Work Agencies'. The suggestions and criticisms of the anonymous reviewers are also gratefully acknowledged.

\section{References}

Abrahamsson, L. and L. Gonäs (2014), Jämställd arbete? Organisatoriska ramar och villkor $i$ arbetslivet SOU 2014:30 [Swedish Government Official Reports] (Stockholm: Regeringskansliet).

Acker, J. (1990), 'Hierarchies, Jobs, Bodies: A Theory of Gendered Organizations', Gender $\mathcal{E}$ Society 4, 2, 139-158.

Acker, J. (2006a), Class Questions. Feminist Answers. (Lanham: Rowman \& Littlefield Publishers Inc).

Acker, J. (2006b), 'Inequality Regimes: Gender, Class, and Race in Organizations', Gender $\mathcal{E}$ Society 20, 4, 441-464. doi:10.1177/0891243206289499.

Acker, J. (2009), 'From Glass Ceiling to Inequality Regimes', Sociologie du Travail 51, 2, 199-217. doi:10.1016/j.soctra.2009.03.004.

Acker, J. (2012), 'Gendered Organizations and Intersectionality: Problems and Possibilities', Equality, Diversity and Inclusion: An International Journal 31, 3, 214-224.

Adams, S.M. and J.W. Weiss (2011), 'Gendered Paths to Technology Leadership', New Technology, Work and Employment 26, 3, 222-237.

Agapiou, A. (2002), 'Perceptions of Gender Roles and Attitudes Toward Work Among Male and Female Operatives in the Scottish Construction Industry', Construction Management and Economics 20, 8, 697-705.

Atkinson, J. (1984), Manpower Strategies for Flexible Organisations." Personnel Management. 16, 8, 28-31

Barley, S.R. and G. Kunda (2004), Gurus, Hired Guns, and Warm Bodies. Itinerant Experts in a Knowledge Economy. (Princeton, NJ: Princeton University Press).

Benshop, Y. and H. Doorewaard (2012), 'Gender Subtext Revisited', Equality, Diversity and Inclusion: An International Journal 31, 3: 225-235.

Crevani, L. and T. Shinozaki Lennerfors (2009), 'Pull yourselves together, guys! A gendred critique of project managers'ethics in a public sector context', Ephemera: Theory \& Politics in Organization 9, 2, 113-130.

Dainty, A.R.J., B.M. Bagilhole, K.H. Ansari and J. Jackson (2004), 'Creating Equality in the Construction Industry: An Agenda for Change for Women and Ethnic Minorities', Journal of Construction Research 5, 1, 75-86.

Dubois, A. and L.-E. Gadde (2002), 'Systematic Combining: An Abductive Approach to Case Research', Journal of Business Research 55, 7, 553-560.

Eriksson-Zetterquist, U. and D. Knights (2004), 'Stories about Men Implementing and Resisting New Technologies', New Technology, Work and Employment 19, 3, 192-206. doi:10.1111/j.1468-005X.2004.00137.x. 
Fielding, J. (2001), 'Coding and Managing Data', in N. Gilbert (ed.), Researching Social Life, 2nd edn (London: SAGE Publications Ltd), pp. 227-251.

Fielding, N. and H. Thomas (2001), 'Qualitative Interviewing', in N. Gilbert (ed.), Researching Social Life, 2nd edn (London: SAGE Publications Ltd), pp. 123-144.

Gale, A. (1994), 'Women in Non-traditional Occupations', Women in Management Review 9, 2, 3-14.

Gale, A. and S. Cartwright (1995), 'Women in Project Management: Entry into a Male Domain? A Discussion on Gender and Organizational Culture', Leadership E Organizational Development Journal 16, 2, 3-9.

Garsten, C. (2003), 'Colleague, Competitor, or Client: Social Boundaries in Flexible Work Arrangements', in N. Paulsen and T. Hernes (eds), Managing Boundaries in Organizations (New York, NY: Palgrave Macmillan), pp. 244-261.

Green, S. (2006), 'The Management of Projects in the Construction Industry: Context, Discourse and Self-identity', in D. Hodgson and S. Cicmil (eds), Making Projects Critical (New York, NY: Palgrave Macmillan), pp. 232-251.

Greene, J. (2007), Mixed Methods in Social Inquiry. (San Francisco, CA: John Wiley \& Sons).

Grimshaw, D., M. Marchington, J. Rubery and H. Willmott (2005), 'Introduction: Fragmenting Work Across Organizational Boundaries', in M. Marchington, D. Grimshaw, J. Rubery, and H. Willmott (eds), Fragmenting Work. Blurring Organizational Boundaries and Disordering Hierarchies (New York, NY: Oxford University Press), pp. 1-38.

Healy, G., H. Bradley and C. Forson (2011), 'Intersectional Sensibilities in Analysing Inequality Regimes in Public Sector Organizations', Gender, Work \& Organization 18, 5, 467-487. doi:10.1111/j.1468-0432.2011.00557.x.

Hodgson, D. (2002), 'Disciplining the Professional: The Case of Project Management', Journal of Management Studies 39, 6, 803-821.

IBM (2013), IBM SPSS Statistics for macintosh, Version 20.0. Armonk, NY: IBM Corp..

Kalleberg, A.L. (2000), 'Nonstandard Employment Relations: Part-Time, Temporary and Contract Work', Annual Review of Sociology 26, 341-365.

Kalleberg, A.L. (2001), 'Organizing Flexibility; The Flexible Firm in a New Century', British Journal of Industrial Relations 39, 4 (December 2001), 479-504.

Kalleberg, A.L. (2003), 'Flexible Firms and Labor Market Segmentation. Effects of Workplace Restructuring on Jobs and Workers', Work and Occupations 30, 2, 154-175.

Kalleberg, A.L. (2009), 'Precarious Work, Insecure Workers: Employment Relations in Transition', American Sociological Review 74, 1, 1-22. doi:10.2307/27736045.

Kalleberg, A.L. (2013), Good Jobs, Bad Jobs: The Rise of Polarized and Precarious Employment Systems in the United States, 1970s-2000s. (New York, NY: Russel Sage Foundation).

Kalleberg, A.L., J. Reynolds and P.V. Marsden (2003), 'Externalizing Employment: Flexible Staffing Arrangements in US Organizations', Social Science Research 32, 525-552.

Lindgren, M. and J. Packendorff (2006), 'What's New in New Forms of Organizing? On the Construction of Gender in Project-Based Work', Journal of Management Studies 43, 4, 841-866. doi:10.1111/j.1467-6486.2006.00613.x.

Marshall, N. (2003), 'Identity and Difference in Complex Projects: Why Boundaries Still Matter in the "Boundaryless" Organization', in N. Paulsen, and T. Hernes (Eds), Managing Boundaries in Organizations. Multiple Perspectives (Houndmills, Basingstoke, Hampshire: Palgrave Macmillan), pp. 55-75.

Miles, M.B. and A.M. Huberman (1994), Qualitative Data Analysis: An Expanded Sourcebook, 2nd edn. (Thousands Oaks, CA: SAGE Publications Ltd).

Mulinari, P. and R. Selberg (2013), 'Intersectional Directions in Working Life Research - A Proposal', Nordic Journal of Working Life Studies 3, 3, 81-98.

Ness, K. (2012), 'Constructing Masculinity in the Building Trades: 'Most Jobs in the Construction Industry Can Be Done by Women", Gender, Work \& Organization 19, 6, 654-676. doi:10 $.1111 /$ j.1468-0432.2010.00551.x.

Oakley, J. (2000), 'Gender-based Barriers to Senior Management Positions: Understanding the Scarcity of Female CEOs', Journal of Business Ethics 27, 4, 321-334. doi:10.102 3/A:1006226129868.

Paap, K. (2006), Working Construction: Why White Working-Class Men Put Themselves- and the Labor Movement -In Harms Way. (New York, NY: Cornell University).

Paton, S., D. Hodgson and D. Muzio (2013), 'The Price of Corporate Professionalisation: Analysing the Corporate Capture of Professions in the UK', New Technology, Work and Employment 28, 3, 227-240. doi:10.1111/ntwe.12014.

Pedhazur, E.J. and L.P. Schmelkin (1991), Measurement, Design, and Analysis: An Integrated Approach. (Hillsdale, NJ: Lawrence Erlbaum Associates). 
Purcell, K. and J. Purcell (1998), 'In-sourcing, Outsourcing, and the Growth of Contingent Labour as Evidence of Flexible Employment Strategies', European Journal of Work and Organizational Psychology 7, 1, 39-59. doi:10.1080/135943298398952.

Reilly, P.A. (1998), 'Balancing Flexibility - Meeting the Interests of Employer and Employee', European Journal of Work and Organizational Psychology 7, 1, 7-22.

Sappleton, N. and H. Takruri-Rizk (2008), 'The Gender Subtext of Science, Engineering, and Technology (SET) Organizations: A Review and Critique', Women's Studies 37, 3, 284-316. doi:10.1080/00497870801917242.

SCB. (2014), The Occupational Structure in Sweden 2012 - Occupational Statistics Based on the Swedish Occupational Register AM 33 SM 1401, http://www.scb.se. Accessed 23.11.2015

Srinivas, S. (2011), 'Occupational Matching into Science and Technology Jobs-Gender-based Differences', New Technology, Work and Employment 26, 2, 146-155. doi:10.1111/j.1468-005X .2011.00265.x.

Statskontoret. (2009), Sega gubbar? En uppföljning av Byggkommissionens Betänkande "Skärpning gubbar!" (Vol. 2009:3), (Stockholm: Statskontoret).

Strauss, A. and J. Corbin (1998), Basics of Qualitative Research. Techniques and Procedures for Developing Grounded Theory, Vol 2nd edn. (Thousands Oaks, CA: SAGE Publications Inc).

Styhre, A. (2011), 'The Overworked Site Manager: Gendered Ideologies in the Construction Industry', Construction Management and Economics 29, 9, 943-955. doi:10.1080/01446193.20 11.588955.

Voudouris, I. (2007), ‘The Co-evolution of Functional and Numerical Flexibility: Do Technology and Networking Matter?', New Technology, Work and Employment 22, 3, 224-245. doi:10.1111/j.14 68-005X.2007.00196.x.

Wajcman, J. (1998), Managing Like a Man. (Oxford: Blackwell).

Wajcman, J. (2008), 'Life in the Fast Lane? Towards a Sociology of Technology and Time', The British Journal of Sociology 59, 1, 59-77.

Watts, J.H. (2007), 'Porn, Pride and Pessimism: Experiences of Women Working in Professional Construction Roles', Work, Employment \& Society 21, 2, 299-316. doi:10.1177/0950017007076641.

Watts, J.H. (2009a), “'Allowed into a Man's World” Meanings of Work-Life Balance: Perspectives of Women Civil Engineers as "Minority" Workers in Construction', Gender, Work \& Organization 16, 1, 37-57.

Watts, J.H. (2009b), 'Leaders of Men: Women 'Managing' in Construction', Work, Employment $\mathcal{E}$ Society 23, 3, 512-530. doi:10.1177/0950017009337074.

Yeow, J. (2014), 'Boundary Management in an ICT-enabled Project-based Organising Context', New Technology, Work and Employment 29, 3, 237-252. doi:10.1111/ntwe.12036. 